\title{
PENINGKATAN AKTIVITAS DAN PRESTASI BELAJARMELALUI PENDEKATAN SAINTIFIK PADA MATA PELAJARAN IPA MATERI ALAT INDRA DAN PEMELIHARAANYA KELAS IV SD N 2 KALIBENING KABUPATEN WONOSOBO TAHUN AJARAN 2017/2018
}

\author{
Herman \\ Panji Hidayat \\ PGSD FKIP Universitas Ahmad Dahlan \\ hermanher211@gmail.com
}

\begin{abstract}
The process of teaching and learning activities of science subjects The material of the Indra and Maintenance Equipment which is usually done is lecture and only emphasize on the book. Teaching activities centered on teachers. Learners prefer to listen and record rather than ask or express opinions. Passive state of learners make a mistake pahama concept of teaching materials. The scientific approach is expected to increase activity and learning achievement. This study is a classroom action research consisting of two cycles. Subjects in this study were students class IV SD N 2 Kalibening 2017/2018 academic year which amounted to 20 children. Data collection techniques include observation, tests, interviews, and field notes. Data analysis using quantitative and qualitative analysis. The success criteria of action are said to be active if the number of active learners reaches $61 \%-80 \%$. Criteria for the success of science learning achievement The material of Indra and Pemelihraanya which escaped KKM is $75 \% \geq 81 \%$.

The results showed that learning with scientific approach has increased. Improvement can be seen in terms of activity and learning achievement of learners. In cycle I the percentage of activity reached 50\% and increased in cycle II to reach $74 \%$. Percentage increase in cycle I is 55\% and increase in cycle II by 90\%. It is concluded that the application of scientific approach can improve the activity and learning achievement of the fourth grade students of SD N 2 Kalibening in the science learning of the material of the sensory equipment and its maintainers.
\end{abstract}

Keywords: Activity, Learning Achievement, Scientific Approach

\begin{abstract}
ABSTRAK
Proses kegiatan belajar mengajar mata pelajaran IPA Materi Alat Indra dan Pemeliharaanya yang biasa dilakukan adalah ceramah dan hanya menekankan pada buku. Kegiatan pembelajaran berpusat pada guru. Peserta didik lebih suka mendengarkan dan mencatat dari pada bertanya maupun mengutarakan pendapat. Keadaan peserta didik yang pasif menjadikan kesalah pahama konsep materi ajar. Pendekatan saintifik diharapkan dapat meningkatkan aktivitas dan prestasi belajar. Penelitian ini merupakan penelitian tindakan kelas yang terdiri atas dua siklus. Subjek dalam penelitian ini adalah peserta didik kelas IV SD N 2 Kalibening tahun ajaran 2017/ 2018 yang berjumlah 20 anak. Teknik
\end{abstract}


pengumpulan data meliputi observasi, tes, wawancara, dan catatan lapangan. Analisis data menggunakan analisis kuantitatif dan kualitatif. Kriteria keberhasilan tindakan dikatakan aktif jika jumlah peserta didik yang aktif mencapai 61\%-80\%. Kriteria keberhasilan prestasi belajar IPA Materi Alat Indra dan Pemelihraanya yang lolos KKM yaitu 75 adalah $\geq 81 \%$.

Hasil penelitian menunjukkan bahwa pembelajaran dengan pendekatan saintifik mengalami peningkatan. Peningkatan dapat dilihat dari segi aktivitas maupun prestasi belajar peserta didik. Pada siklus I persentase aktivitas mencapai 50\% dan meningkat pada siklus II hingga mencapai $74 \%$. Persentase mengalami peningkatan pada siklus I yaitu $55 \%$ dan meningkat pada siklus II sebesar 90\%. Disimpulkan bahwa penerapan pendekatan saintifik dapat meningkatkan aktivitas dan prestasi belajar peserta didik kelas IV SD N 2 Kalibening pada pembelajaran IPA Materi Alat Indra dan Pemeliharaanya.

Kata kunci : Aktivitas, Prestasi Belajar, Pendekatan Saintifik

\section{PENDAHULUAN}

Menurut PP Nomor 19 Tahun 2005 Tentang Standar Nasional Pendidikan pada hakekatnya pendidikan dalam konteks pembangunan nasional mempunyai fungsi pemersatu bangsa, penyamaan kesempatan, dan pengembangan potensi diri. Pendidikan diharapkan memperkuat keutuhan bangsa dalam negara kesatuan republik indonesia,memberi kesempatan yang sama bagi setiap warga negara untuk berpartisipasi dalam pembangunan, dan memungkinkan setiap warga negara untuk mengembangkan potensi yang dimilikinya secara optimal.

Salah satu isu yang banyak disoroti dalam dunia pendidikan saat ini adalah rendahnya pencapaian hasil pendidikan yang diperoleh peserta didik, terutama pada jalur formal di jenjang pendidikan dasar. Pendidikan tingkat Sekolah Dasar (SD) bertujuan untuk memberikan bekal kemampuan dasar kepada siswa untuk mengembangkan kehidupan sebagai pribadi, anggota masyarakat, warga negara dan umat manusia serta mempersiapkan peserta didik untuk mengikuti pendidikan selanjutnya (Azwar, 2010:8). Kelemahan dalam mempersiapkan dan memberikan bekal pengetahuan dan kemampuan kepada peserta didik di tingkat sekolah dasar, akan berpengaruh terhadap pencapain hasil pendidikan di tingkat selanjutnya. Rendahnya pencapaian mutu hasil pendidikan di tingkat sekolah dasar, cenderung akan mempengaruhi rendahnya pencapaian hasil pendidikan di tingkat selanjutnya. Di era pembangunan saat ini, dimana situasi kehidupan semakin mengglobal maka sangat dibutuhkan sumber daya indonesia yang berkualitas tinggi.

Tanpa memiliki kemampuan sumber daya manusia yang berkualitas tinggi dan mampu bersaing dengan bangsa-bangsa lain, hanya akan menempatkan pada posisi tidak atau kurang dapat memanfaatkan situasi yang ada, terutama untuk mencapai perbaikan hidup. Untuk menciptakan sumber daya manusia indonesia yang berkualitas tinggi, maka salah satu bidang studi yang harus dipelajari oleh peserta didik di tingkat Sekolah Dasar adalah Ilmu Pengetahuan Alam, agar peserta didik mampu dalam memenuhi kebutuhan manusia melalui pemecahan masalah yang dapat diidentifikasi, dan diterapkan dalam lingkungan masyarakat.

Menurut Hayat dan Yusuf (Widi, 2014) Hasil belajar IPA yang dicapai oleh peserta didik di Indonesia yang tergolong rendah dipengaruhi oleh banyak faktor, minat dan konsep diri, strategi belajar, tingkat kehadiran dan rasa memiliki. Faktor yang sangat adalah lingkungan belajar peserta didik dalam bentuk strategi yang diciptakan guru dalam mengoptimalkan potensi-potensi yang dimiliki peserta didik dalam mempelajari IPA. Dan menggunakan konsep IPA tersebut dalam memahami lingkungan. Maka sebagai pendidik guru harus menguasai banyak stategi dan metode dalam mengajarka IPA. Guru harus 
kreatif dalam mengajar agar dapat menjelaskan materi secara benar dengan suasana yang nyaman dan menyenangkan. konkret, maka dalam proses pembelajaran IPA yang abstrak harus dibantu agar menjadi lebih konkret. Hal ini berati bahwa strategi pembelajaran IPA haruslah sesuai dengan perkembangan intelektual atau perkembangan tingkat berfikir anak, sehingga diharapkan pembelajaran IPA di Sekolah Dasar itu lebih efektif dan menyenangkan. Pada dasarnya proses pembelajaran pada setiap satuan pendidikan dasar harus interaktif, inspiratif, menyenangkan, menantang, dan memotivasi peserta didik untuk berpartisipasi aktif, serta memberikan ruang yang cukup bagi prakarsa, kreativitas.

Pembelajaran IPA di SD merupakan sarana tepat untuk mempersiapkan para siswa agar memperoleh pengetahuan-pengetahuan yang baru sehingga apa yang mereka peroleh dapat dipergunakan dalam kehidupan sehari-hari. Tetapi pada kenyataanya prestasi belajar siswa dalam mempelajari konsep-konsep dalam IPA tida sesuia oleh harapan guru, hal ini dikarenakan anggapan bahwa pengetahuan itu bisa di transfer dari pikiran seseorang ke pikiran orang lain, sehingga guru yang aktif dalam plembelajaran untuk memindahkan pengetahuan yang dimilikinya seperti mesin siswa hanya mendengar, mencatat dan mengerjakan tugas yang diberikan guru sehingga pembelajaran berpusat pada guru dan pemahaman yang dicapai siswa brsifat sementara.

Selain itu, penyebab rendahnya aktifitas dan prestasi belajar IPA yaitu dalam penyampaian pelajaran IPA masih sering menggunakan metode yang monoton dan cenderung konvensional seperti ceramah. Penggunaan metode tersebut yang mungkin dianggap para guru adalah metode paling praktis, mudah dan efisien sehingga dapat dilaksanakan tanpa persiapan. Namun dalam pembelajaran yang hanya menggunakan metode tersebut akan membuat siswa menjadi pasif dan mudah bosan di kelas. Sehingga siswa menjadi kurang optimal dalam memahami pelajaran IPA yang kemandirian sesuai dengan bakat, minat dan perkembnagan fisik, serta psikologis peserta didk (Rusman, 2010:4) Maka guru sebagai pendidik wajib membimbing dan mengajarkan IPA dengan baik agar tujuan pembelajaran IPA dan proses pembelajaran sekolah Dasar dapat tercapai. disampaiakan oleh guru dan menyebabkan prestasi belajar siswa dalam pelajaran IPA masih jauh dari harapan guru. Demikian juga berdasarkan hasil observasi kegiatan pembelajaran pada kelas IV SDN 2 Kalibening Kecamatan Sukuharjo Kabupaten Wonosobo bahwa pembelajaran masih sering menggunakan metode yang monoton dan cenderung konvensional sehingga menjadikan siswa kurang aktif dan mudah bosan dalam pembelajaran.

Berdasarkan hasil wawancara dengan guru kelas mengenai aktivitas belajar memberikan kesempatan kepada peserta didik untuk bersentuhan dengan obyek yang sedang dipelajari seluas mungkin, karena dengan demikian proses kontruksi pengetahuan yang terjadi akan lebih baik. aktifitas belajar memerlukan aktivitas, sebab pada prinsipnya belajar adalah berbuat mengubah tingkah laku, melakukan kegiatan. Belajar membutuhkan aktivitas. Tanpa ada aktivitas, proses belajar tidak mungkin terjadi. Aktifitas peserta didik selama proses belajar di SD 2 Kalibening ternyata belum optimal, salah satunya adalah peserta didik yang pasif dalam proses pembelajaran. Selain itu dalam penggunaan media pembelajaran belum terlihat keinovasianya seperti menggunakan media power poin dan sebagainya.

Berdasarkan nilai ulangan mata pelajaran IPA pula yang berkaitan dengan materi kerangka pada manusia menunjukan bahwa prestasi siswa kelas IV SDN 2 Kalibening banyak yang jauh dari harapan guru dan masih di bawah KKM (Kreteria Ketuntasan Minimal ) yaitu 75. Dari hasil ulangan IPA tebrsebut yang mencapai KKM adalah sebanyak 8 siswa atau 16,67\% dari jbumlah siswa dan yang tidak tuntas sebanyak 12 siswa atau $83,33 \%$ darib jumlah siswa. Untuk mengatasi masalah tersebut perlu ada tindakan yang tepat agar proses kegiatan belajar mengajar mampu mencapai tujuanya. Dalam hal ini 
peneliti ingin mencoba menggunakan metode pembelajaran saintifik untuk masalah tersebut. Berdasarkan paparan masalah diatas maka penulis bermaksud membuat penelitian dengan judul: Peningkatan Aktivitas dan Belajar Melalui Pendekatan Saintifik Pada Materi Alat Indra dan Pemeliharaanya Pada Mata Pelajaran IPA Peserta Didik Kelas IV SD 2 Kalibening Tahun Ajaran 2017/2018.

Aktivitas belajar merupakan aktifitas peserta didik adalah keterlibatan peserta didik dalam bentuk sikap, pikiran, perhatian dan aktivitas dalam kegiatan pembelajaran guna menunjang keberhasilan proses belajar mengajar dan memperoleh manfaat dari kegiatan tersebut (Kusnandar, 2011). "Aktivitas merupakan prinsip yang penting di dalam interaksi belajar mengajar, sebagai rasionalitasnya hal ini juga mendapatkan pengakuan dari berbagai ahli pendidikan" (Sardiman A.M,2011). Aktifitas merupakan hal penting bagi peserta didik, karena memberikan kesempatan kepada peserta didik untuk mempelajari materi ajar seluas mungkin.

Prestasi belajar diartikan sebagai prestasi yang dicapai oleh seseorang siswa pada jangka waktu tertentu dan dicatat dalam buku rapor sekolah (Poerwodarminto Mila Ratna Wati dalam Basri, 2015). Menurut Yaspir Gandhi Wirawan dalam Murjono (dalam Basri, 2015) menjelaskan bahwa prestasi belajar adalah hasil yang dicapai seorang siswa dalam usaha belajarnya sebagai mana di cantumkan nilai rapornya. Syaiful Bahri Djamara(dalam Umiarso,2011) menjelaskan bahwa prestasi belajar adalah hasil yang diperoleh berupa kesan-kesan yang mengakibatkan perubahan dalam diri individu sebagai hasil dari kreatifitas belajar. Sehingga prestasi belajar tidak dapat dipisahkan dari kegiatan belajar karena belajar merupakan suatu proses,sedangkan prestasi belajar adalah hasil dari proses belajar tersebut.

Daryanto (2014) menyatakan bahwa pembelajaran dengan pendekatan saintifik merupakan proses pembelajaran yang dirancang sedimikian rupa agar peserta didik secara aktif mengkonstuksi konsep, hukum atau prinsip melalui tahapan-tahapan, tahapan-tahapan yang dimaksud dalam pengertian ini adalah tahapan peserta didik dalam mengamati, merumuskan masalah, merumuskan hipotesis, mengumpulkan data, analisis data, kemudian menarik kesimpulan dan mengkomunikasikan. Dengan demikian, peserta didik mengetahui secara nyata mengenai apa yang mereka pelajari. Pembelajaran saintifik adalah pembelajaran ilmiah yang pada dasarnya memberi pengalaman secara nyata kepada peserta didik untuk memperoleh pengetahuan berdasarkan metode dan langkah ilmiah secara mandiri. Sehingga guru memfasilitasi peserta didik untuk menemukan pengetahuan. Dengan demikian, peserta didik memiliki makna dari pengetahuan yang ia pelajari karena terdapat proses mengamati, menanya, mencari data, menyimpulkan, dan mengkomunikasikan hasil yang ia peroleh.

Langkah-langkah pendekatan saintifik, yaitu mengamati atau observasi merupakan panca penggunaan panca indera untuk memperoleh informasi. Seblum memulai pembelajaran materi, peserta didik dapat mengobservasi media atau perangkat yang disediakan guru. Misalnya peserta didik mengobservasi warna, tekstur, bentuk, susu, dan bau sesuatu benda (Sani,2014). Menanya, menurut Permendikbu No. 81a Tahun 2013 (dalam, daryanto, 2014) menjelaskan bahwa kegiatan menanya merupakan kegiatan bertanya untuk mendapatkan informasi tambahan mengenai apa yang diamati dan dipelajari. Dengan bertanya maka akan mengembangkan kreativitas, rasa ingin tahu, kemampuan, merumuskan pertanyaan untuk membentuk pikiran kritis pada peserta didik. Melakukan eksperimen/percobaan atau memperoleh informasi, Daryanto (2014) "kegiatan mengumpulkan informasi dilakukan dengan menggali dan mengumpulkan informasi dari berbagai sumber melalui berbagai cara. Berbagai cara yang dimaksudkan yaitu dapat dilakukan dengan membaca buku, mengamati secara langsung, maupun mengadakan percobaan guna memperoleh informasi. Mengasosiasi atau menalar menurut Kosasih 
(2014) dalam pendekatan saintifik, "mengasosiasikan diartikan sebagai menerapkan (mengembangkan, memperdalam) pemahaman atas suatu konsep kepada konsep ain yang sejenis atau yang berbeda". Peserta didik dapat menambah keleluasaan dan kedalaman pemahaman dengan mengaitkan pemahaman sebelumnya baik yang sejenis maupun bertentangan. Dengan demikian maka pengetahuan peserta didik akan menjadi luas dan tidak terpaku pada suatu konteks. Mengkomunikasikan, Kosasih (2014) menjelaskan bahwa "mengkomunikasikan berarti menyampaikan hasil kegiatan sebelumnya kepada orang lain, baik secara lisan maupun tertulis". Apabila secara lisan maka peserta didik dapat membacakan pendapat pribadi maupun hasil diskusi untuk mendapatkan tanggapan dari peserta didik lain. Selain itu peserta didik juga mengomunikasikan dengan alat bantu tertulis seperti LCD sehingga lebih dipahami peserta didik lain.

IPA merupakan matapelajaran wajib pada kurikulum KTSP di sekolah dasar. IPA di SD membuka kesempatan untuk memupuk rasa ingin tahu siswa secara alamiah. Cullingford dalam Samartowa (2010) mengemukakan bahwa dalam pembelajaran IPA, siswa harus diberi kesempatan untuk mengembangkan sikap ingin tahu dan berbagai penjelasan logis. Hal ini tentunya penting, agar siswa tidak hanya dijejali dengan teori saja tanpa mengetahui proses bagaimana teori itu dapat terbentuk, sehingga siswa harus lebih memfokuskan diri untuk menerima materi yang sedang diajarkan Oleh karena itu, pembelajaran IPA di sekolah selanjutnya(1) memberikan pengalaman pada siswa sehingga mereka kompeten melakukan pengukuran berbagai besaran fisik, (2) menanamkan pada siswa pentingnya pengamatan empiris dalam menguji suatu pernyataan ilmiah ( hipotesis) . Hipotesis ini dapat berasal dari pengamatan terhadap kejadian sehari-hari yang memerlukan pembuktian secara ilmiah, (3) latihan berpikir kuantitatif yang mendukung kegiatan belajar metematika, yaitu sebagai penerapan matematika pada masalah-masalah nyata yang berkaitan dengan peristiwa alam, (4) memperkenalkan dunia teknologi melalui kegiatan kreatis dalam kegiatan perancangan dan pembuatan alat-alat sederhana maupun penjelasan berbagai gejala dan kemampuan IPA dalam menjawab berbagai masalah.

\section{METODE PENELITIAN}

Penelitian ini berbentuk Penelitian Tindakan Kelas (PTK) atau Clasroom Action Research $(C A R)$. Penelitian tindakan kelas yang memuat unsur perencanaan, pelaksanaan, pengamatan, dan refleksi. Digunakan PTK karena bertujuan untuk meningkatkan proses dan hasil belajar peserta didik di kelas, sehingga dapat memperbaiki pembelajaran yang belum maksimal. Penelitian Tindakan Kelas ini menggunakan model spiral Suharsimi (2012: 16) dengan siklus yang berisi tahapan-tahapan perencanaan, pelaksanaan, pengamatan/observasi dan refleksi. Model tersebut digambarkan sebagai berikut.

a. Tahap Perencanaan

Perencanaan merupakan langkah awal yang dilakukan sebelum melaksanakan tindakan. Tahap perencananaan ini menjelaskan tentang apa, mengapa, kapan, dimana, oleh siapa, dan bagaimana tindakan tersebut dilakukan. Dalam pelaksaan pembelajaran rencana tindakan dalam rangka penelitian dituangkan dalam bentuk RPP (Rencana Pelaksanaan Pembelajaran).

b. Tahap Pelaksanaan

Pelaksanaan merupakan implementasi dari rencana yang telah dibuat. Dalam tahap pelaksanaan suatu kegiatan atau program membutuhkan persiapan yang matang, baik persiapan dari pihak pelaksanaan, subjek yang menjadi partisipan dari pihak pelaksana, subjek yang menjadi partisipan dalam kegiatan, maupun faktor-faktor yang mendukung pelaksanaan berlangsung, diadakan evaluasi dan monitoring atau 
pengumpulan data. Dari data yang diperoleh pada tahap ini digunakan sebagai patokan dalam penyempurnaan rancangan dan pelaksanaan tindakan berikutnya.

c. Tahap Observasi (Pengamatan) Observasi merupakan proses dimnaseorangpelaksana melakukan pengamatan terhadap subjek yang diteliti. Dalam tahap observasi ini tidak dapat dipisahkan dari tahap pelaksanaan, karena keduanya berlangsung dalam waktu yang sama.

d. Tahap Refleksi

Refleksi merupakan kegiatan mengingat dan mengemukakan kembali kegiatan yang sudah lampau, apa yang sudah dilakukan guru maupun peserta didik. Kegiatan refleksi ini dilakukan setelah guru selesai melaksanakan tindakan. Kemudian melaksanakan penyimpulan dari tindakan yang sudah dilakukan hal-hal yang dirasakan sudah bagus sesuai rancangan dan mengenali hal-hal yang masih perlu diperbaiki. Jadi pada intinya kegiatan refleksi merupakan kegiatan evaluasi, analisis, pemaknaan, penjelasan, penyimpulan, dan identifikasi tindakan lanjut dalam perencanaan siklus selanjutnya. penelitian tindakan kelas ini terdiri dari dua siklus, Setiap tindakan yang dilakukan merupakan refleksi dari tindakan sebelumnya, perencanaan pada siklus selanjutnya berdasarkan refleksi, pada siklus sebelumnya, dengan menunjukan kelemahan siklus tersebut, kemudian dijelaskan bagaimana kelemahan tersebut akan diperbaiki.

\section{SIKLUS I}

Tindakan pada siklus I meliputi empat tahap kegiatan yaitu perencanan, pelaksanaan, pengamatan, serta refleksi.

a. Perencanaan

1) Mempersiapkan RPP (Perencanaan Pelaksanaan Pembelajaran) pokok bahasan alat indera manusia dan pemeliharaannya, dengan sub pokok bahasan alat indera mata manusia.

2) Mempersiapkan materi IPA pokok bahasan alat indera manusia dan pemeliharannya dengan sub pokok bahasan alat indera manusi.

3) Membuat lembar observasi kegiatan peneliti dan lembar observasi kegiatan siswa.

4) Membuat lembar soal post test untuk mengetahui peningkatan prestasi belajar siswa.

5) Menyiapkan media dan alat peraga untuk menunjang proses pembelajaran.

b. Pelaksanaan Pada tahap ini peneliti melaksanakan proses pembelajaran berdasarkan Rencana Pelaksanaan Pembelajaran (RPP) yang telah direncanakan. Skenario pembelajaran dilakukan bersammaan dengan observasi terhadap dampak tindakan.

c. Pengamatan

1) Keterlibatan siswa dalam pembelajaran masih kurang, dimana siswa belum aktif dalam kegiatan pembelajaran karena model yang digunakan belum sepenuhnya menarik perhatian siswa.

2) Keterlibatan guru dalam proses pembelajaran juga masih kurang, dimana langkahlangkah penerapan saintifik yang dilakukan guru masih kurang cakap, serta dalam pelaksanaan alokasi waktu dan pengelolaan kelas masih kurang.

d. Refleksi

Adapun hasil refleksi dari siklus 1 adalah sebagai berikut :

1) Guru kurang mampu memotivasi siswa ketika pembelajaran.

2) Guru kurang mampu mengkondisikan siswa untuk membentuk kelompok.

3) Guru kurang cakap dalam menyampaikan materi.

4) Guru kurang mampu dalam menghitung skor yang diperoleh siswa bersama-sama siswa.

5) Guru juga belum terlalu cakap dalam pengelolaan kelas dan pengelolaan waktu. 
6) Siswa belum aktif dalam kegiatan pembelajaran karena siswa belum terbiasa dalam memahami jalannya strategi pembelajaran pendekatan saintifik yang diterapkan sehingga belum menarik perhatian siswa.

7) Siswa kurang aktif untuk bertanya.

8) Siswa masih sering gaduh dalam kelas.

Berdasarkan uraian diatas dapat disimpulkan bahwa pelaksanaan tindakan pada siklus I belum berhasil. Dengan demikian perlu dicari kelemahan yang ada pada tindakan I untuk kemudian dapat ditentukan perbaikan-perbaikannya.

\section{SIKLUS II}

Pada siklus II perencanaan tindakan dikaitkan dengan hasil yang telah dicapai pada tindakan siklus satu sebagai upaya perbaikan dari siklus tersebut dengan pendekatan saintifik. Tahapan yang dilakukan pada siklus kedua sama dengan siklus yang pertama. Sebelum membuat keputusan untuki melanjutkan siklus kedua, peneliti terlebih dahulu mencermati catatan keberhasilan dan hambatan yang dihadapi pada waktu pelaksanaan tindakan. Setelah itu peneliti menganalisis data dengan membandingkan anatara kondisi awal dengan kondisi akhir. Siklus dihentikan apabila indikator sudah tercapai.

Data kuatitatif merupakan data berupa bilangan, nilainya bisa berubah-ubah atau bersifat variatif. Pengiolahan data secara kuantitatif bertujuan untuk mengetahui peningkatan aktivitas dan prestasi belajar peserta didik setelah proses pembelajaran. Hasil presantasi aktivitas belajar peserta didik secara umum adalah jumlah peserta didik dalam perolehan skor, di bagi jumlah peserta didik keseluruhan yaitu 20 anak dan dikalikan $100 \%$. Untuk menuntaskan presentase peserta didik yang aktif dihitung dengan rumus sebagai berikut (Sudijono,2012).

$$
\begin{aligned}
& P(\%)=\frac{f}{\mathrm{~N}} \times 100 \% \\
& \text { Keterangan: } \\
& \mathrm{P} \text { : presentasi siwa yang aktif } \\
& f \text { : freekuensi yang sedang } \\
& \text { dicari presenya( jumlah siswa } \\
& \text { yang aktif) } \\
& \bar{x}=\frac{\sum \mathrm{x}}{n} \\
& \bar{x} \quad=\text { Rata-rata } \\
& \sum x=\text { Jumlah Seluruh Skor } \\
& N=\text { Jumlah Siswa } \\
& \text { Sedangkan untuk } \\
& \text { presentase peserta didik yang } \\
& \text { mencapai KKM menggunakan } \\
& \text { rumus sebagai berikut: } \\
& \mathrm{P}=\frac{\sum \text { siswa yang mencapai KKM }}{\sum \text { siswa keseluruhan }} \times 100 \% \\
& \mathrm{P}=\text { Presentase ketuntasan belajar } \\
& \sum=\text { Jumlah }
\end{aligned}
$$




\section{HASIL DAN PEMBAHASAN}

Peningkatan prestasi belajar selama proses pembelajaran pra tindakan, siklus i, dan ii peserta didik kelas IV SD N 2 Kalibening.

Tabel 1. Hasil Penelitian

\begin{tabular}{ccc} 
Keterangan & $\begin{array}{c}\text { Postest } \\
\text { siklus I }\end{array}$ & $\begin{array}{c}\text { Postest } \\
\text { Siklus II }\end{array}$ \\
\hline Jumlah nilai & 1500 & 1799 \\
\hline Rata-rata & 75 & 89,95 \\
\hline Skor Tertinggi & 90 & 100 \\
\hline $\begin{array}{c}\text { Skor Terendah } \\
\text { Jumlah siswa } \\
\text { Tuntas }\end{array}$ & 50 & 70 \\
\hline $\begin{array}{c}\text { Persentase } \\
\text { Ketuntasan }\end{array}$ & 11 & 18 \\
\hline
\end{tabular}

Hasil dari pelaksanaan tindakan pada siklus I dengan menggunakan pendekatan saintifik, persentase rata-rata aktivitas peserta didik secara keseluruhan diperoleh sebesar $58 \%$. Aktivitas meningkat dengan perolehan kegiatan visual meningkat menjadi $80 \%$, kegiatan lisan 50\%, kegiatan menulis $60 \%$ kegiatan emosional $15 \%$. Secara kualitatif berada pada kategori"cukup aktif" dengan ketuntasan belajar sebesar $50 \%$.

Dilaksanakan kembali tindakan pada siklus II dengan menggunakan pendekatan saintifik, terjadi peningkatan persentase rata-rata aktivitas belajar peserta didik sebesar $76 \%$ dengan kategori "aktif". Aktivitas meningkat dari siklus I ke siklus II dengan perolehan persentase kegiatan visual $98 \%$, kegiatan lisan $70 \%$, kegiatan menulis $74 \%$, dan kegiatan emosional $45 \%$. Peningkatan prestasi belajar pada siklus II juga dapat dilihat dari rata-rata nilai postest yang meningkat dengan ketuntasan belajar sebesar $94 \%$.

\section{KESIMPULAN}

Pembelajaran IPA dengan menggunakan pendekatan saintifik efektif meningkatkan prestasi belajar peserta didik kelas IV di SD Negeri 2 Kalibening. Peningkatan prestasi belajar dibuktikan dengan meningkatnya jumlah peserta didik yang mencapai KKM darisiklus I kesiklus II. Perolehan persentase pada siklus I sebesar $65 \%$ meningkat pada siklus II menjadi 94\%.

Penerapan pendekatan saintifik dapat meningkatkan aktivitas belajar peserta didik kelas IV di SD Negeri 2 Kalibening. Peningkatan aktivitas kegiatan visual dari $85 \%$ pada siklus I meningkat menjadi $100 \%$ pada siklus II. Kegiatan Lisan dari $50 \%$ pada siklus I meningkat menjadi $71 \%$ pada siklus II. Kegiatan menulis dari $62 \%$ pada siklus I meningkat menjadi $74 \%$ pada siklus II.pada siklus I meningkat menjadi $84 \%$ pada siklus II. Kegiatan emosional dari $19 \%$ pada siklus I meningkat menjadi $45 \%$ padasiklus II. Perolehan rata-rata persentase aktivitas peserta didik pada siklus I sebesar 58\% meningkat pada siklus II menjadi $76 \%$.

\section{DAFTAR PUSTAKA}

Azwar,Syaifidin. 2010 Tes Prestasi Fungsi dan Pengembangan Pengukuran Prestasi Belajar. Yogyakarta: Pustaka Pelajar Offset.

Basri, Hasan. 2015. Paradigma Baru Sistem Pembelajaran. Bandung: CV Pustaka Setia.

Daryanto. 2014. Pendekatan Pembelajaran Saintifik Kurikulum 2013.Yogyakarta: Gava Media. 
Kusnandar.2011. Penelitian Tindakan Kelas sebagai Pengembangan Profesi Guru. Jakarta: PT Raja Grafindo Persada.

Kosasih. 2014. Strategi Belajar dan Pembelajaran Implementasi Kurikulum 2013. Bandung: Yrama Weda.

PP RI Nomor 19 Tahun 2005 Tentang Standar Nasioan Pendidikan. Bandung:Fokusmedia.

Rusman. 2012. Belajar dan Pembelajaran Berbasis Komputer. Bandung:Alfabeta.

Sardiman A M. 2011. Interaksi dan Motivasi Belajar Mengajar. Jakarta: PT Raja Grafindo.

Suharsimi \& S.A.J. Cepi. 2012. Evaluasi Program Pendidikan. Jakarta: Bumi Aksara.

Sudijono, Anas. 2012.Pengantar Statistik Pendidikan.Jakarta: Rajawali Pers.

Umiarso dan Imam Gojali. 2011. Manajemen Mutu Sekolah di Era Otonomi Pendidikan. Jogjakarta: IRCiSoD.

Widi,Asih Wisudawati dan Eka Sulistyowati. 2014. Metodologi Pembelajaran IPA.Jakarta:PT.Bumi Aksara. 